\title{
"Ceria"
}

Jurnal Program Studi Pendidikan Anak Usia Dini

ISSN 2301-9905

Volume 7, No. 2, Januari 2018

Fakultas Keguruan dan Ilmu Pendidikan - Universitas Muhammadiyah Tangerang

\section{Pengaruh Kegiatan Mozaik Terhadap Kemampuan Motorik Halus Anak Usia 4-6 Tahun}

\author{
Intan Nursayyidah Wahyudi', Iman Nurjaman ${ }^{2}$ \\ 1,2Program Studi Pendidikan Guru Pendidikan Anak Usia Dini; Fakultas \\ Keguruan Dan Ilmu Pendidikan; Universitas Muhammadiyah Tangerang \\ Email : ${ }^{1}$ intannursayyidah19@gmail.com, ${ }^{2}$ iman.umt@gmail.com
}

\begin{abstract}
Abstrak
Penelitian ini bertujuan untuk mengetahui Pengaruh Kegiatan Mozaik Terhadap Kemampuan Motorik Halus. Penelitian ini dilakukan dengan dua kelompok, yaitu kelompok eksperimen pada kelas B1 dan kelompok kontrol pada kelas B2. Subjek penelitian yang dilibatkan dalam penelitian ini berjumlah 25 siswa kelas B1 dan 25 siswa kelas B2, jumlah keseluruhan ada 50 siswa TK Al-Falahiyyah Rajeg, Kabupaten Tangerang. Metode penelitian ini adalah Quasi Eskperimen, penelitian ini difokuskan pada siswa B1 dan B2. Dan teknik pengumpulan data yang digunakan adalah observasi dan test. Penggunaan uji normalitas menggunakan uji liliefors dan uji homogenitas yaitu menggunakan uji-f. Teknik analisis data yang digunakan untuk menguji hipotesis adalah dengan menggunakan uji-t pada taraf signifikan $a=0,05$. Dengan demikian jika hasil penelitian data diperoleh $t$ hitung (11.636) $>t$ tabel (2.021) hal ini membuktikan bahwa Ho ditolak dan Hi diterima, maka kesimpulan yang diperoleh adalah teknik mozaik berpengaruh positif signifikan terhadap kemampuan motorik halus anak usia 4-6 tahun yang merupakan siswa TK Al-Falahiyyah Rajeg.
\end{abstract}

Kata Kunci: Teknik Mozaik, Kemampuan Motorik Halus, Anak Usia 4-6 Tahun

\section{Pengantar}

Pada hakikatnya manusia adalah makhluk Tuhan yang paling mulia derajatnya dibandingkan dengan makhluk lain ciptaan-Nya. Manusia diciptakan Tuhan dengan segenap potensi yang akan menjadi modal dasar dari perkembangannya. Sebagaimana firman Allah SWT dalam surat An- Nahl ayat 78: "Dan Allah mengeluarkan kamu dari perut ibumu dalam keadaan tidak mengetahui sesuatupun, dan dia memberi kamu pendengaran, penglihatan, dan hati agar kamu bersyukur." (Mushaf Al-Bantani dan Terjemahnya, 2013, h. 275). 
"Ceria”

\section{Jurnal Program Studi Pendidikan Anak Usia Dini}

Ayat di atas mengisyaratkan bahwa pendidikan ini merupakan suatu keharusan agar semua potensi berkembang menuju arah yang positif. Pendidikan harus diberikan pada anak dimulai sejak dini karena memberikan stimulus sejak dini pada anak sangat berpengaruh besar pada tumbuh kembang anak dimasa dewasanya.

Anak usia dini adalah manusia kecil yang sedang mengalami masa kanak-kanak awal, yaitu yang berusia 2 sampai 6 tahun, yang tumbuh kemampuan emosionalnya agar setelah dewasa nanti berkemungkinan besar akan memiliki kecerdasan. Dalam tumbuh-kembang anak, orang tua sangat berperan penting dalam memberikan stimulus dengan melakukan pembiasaan setiap hari dan pembiasaan dilakukan dengan cara yang baik agar aspek perkembangan anak dapat tercapai (Musthofa, 2007, h. 10).

Pada periode emas atau yang lebih dikenal sebagai the golden ages pada masa ini otak anak sedang mengalami pertumbuhan dan perkembangan yang sangat pesat dan otak merupakan kunci utama bagi periode kecerdasan anak. Periode ini dimulai sejak janin dalam kandungan hingga usia 6 (enam) tahun. Pada masa ini, pertumbuhan dan perkembangan otak anak mencapai $80 \%$ dari otaknya di masa dewasa kelak. Artinya, di atas periode ini, perkembangan otaknya hanya $20 \%$ saja (Suyadi, 2010, h. 24). Jadi pada masa emas ini orang tua harus memberikan stimulus yang dapat mengembangan kecerdasaan anak dengan sangat baik, karena pada usia dini tingkat pencapaiannya sangat besar.

Kemampuan motorik meliputi kemampuan motorik kasar dan motorik halus. Motorik kasar merupakan gerakan-gerakan yang menggunakan otot besar seperti, berjalan, berlari, melompat, berjinjit, naik turun tangga dan lain sebagainya, sedangkan motorik halus melibatkan otot dan syaraf yang jauh lebih kecil dan detail seperti, meremas kertas, merobek, menggambar, menulis, dan lain sebagainya (Suyadi, 2010, h. 68-69). Motorik merupakan kematangan yang bergantung pada pusat syaraf dan otot anak, dalam melakukan kegiatan yang dapat mengembangkan otot maupun syaraf anak orang tua harus dapat 
"Ceria"

Jurnal Program Studi Pendidikan Anak Usia Dini

memberikan kegiatan maupun permainan yang dapat menstimulus kemampuan motorik. Dalam kegiatan yang diberikan membutuhkan koordinasi mata dan tangan untuk melatih emosional, fokus, dan gerak motorik yang utama dalam mencapai aspek perkembangan anak.

Kemampuan setiap anak berbeda-beda, karena dipengaruhi oleh pembawaan dan stimulus yang anak dapatkan. Lingkungan mempunyai pengaruh yang sangat besar terhadap kemampuan motorik halus anak karena lingkungan sangat berperan penting dalam mencapai tahap kemampuan motorik halus yang optimal asal mendapatkan stimulasi yang tepat. Semakin banyak yang anak lihat dan dengar, semakin banyak yang ingin diketahuinya

Bagi guru atau pendidik harus dapat menciptakan kondisi pembelajaran yang kondusif bagi proses kemampuan motorik anak. Upaya yang dapat dilakukan pendidik atau guru untuk meningkatkan kemampuan motorik anak adalah melalui media yang kreatif dan menyenangkan bagi anak. Dengan menggunakan media yang kreatif tersebut anak dapat melaksanakan kegiatan yang dapat melatih otot-otot tangan dan melatih koordinasi mata, pikiran dan tangannya.

Pada usia 4-6 tahun tingkat pencapaian yang harus anak capai pada usia ini anak sudah mampu melakukan banyak hal. Tingkat pencapaian anak usia 4-6 tahun yaitu: 1. Membuat garis vertikal, horizontal, lengkung kiri/kanan, miring kiri/kanan, dan lingkaran, 2. Menjiplak bentuk, 3. Mengkoordinasikan mata dan tangan untuk melakukan gerakan yang rumit, 4. Melakukan gerakan manipulatif untuk menghasilkan suatu bentuk dengan menggunakan berbagai media, 5 . Mengekspresikan diri dengan berkarya seni menggunakan berbagai media, 6 . Mengontrol gerakan tangan yang menggunakan otot halus (menjumput, mengelus, mencolek, mengepal, melintir, memilin, dan memeras), 7.Menggambar sesuai gagasannya, 8. Meniru bentuk, 9. Melakukan eksplorasi dengan berbagai media dan kegiatan, 10. Menggunakan alat tulis dan alat makan dengan benar, 11. Menggunting sesuai dengan pola,12. Menempel gambar 
"Ceria"

Jurnal Program Studi Pendidikan Anak Usia Dini

dengan tepat, 13. Mengekspresikan diri melalui gerakan menggambar secara rinci ( Permendikbud No. 137 Tahun 2014).

Berdasarkan hal tersebut, bahwa kemampuan motorik halus anak di TK Al-Falahiyyah, Rajeg, Kabupaten Tangerang cenderung masih belum terstimulus secara optimal. Hal ini ditandai sebagian besar anak yang belum mampu melakukan gerakan motorik halus. Pada kelompok B1 dari 25 orang anak ada 15 orang anak yang motorik halusnya belum berkembang dengan baik dan 10 anak sudah berkembang, dan pada kelompok B2 dari 25 anak 14 yang belum berkembang dan 11 sudah berkembang kemampuan motorik halusnya.

Mozaik suatu karya membutuhkan kreativitas dan keuletan disetiap prosesnya. Mozaik adalah pembuatan karya seni rupa dua atau tiga dimensi yang menggunakan material atau bahan dari kepingan-kepingan yang sengaja dibuat dengan cara dipotong-potong atau sudah berbentuk potongan kemudian disusun dengan ditempelkan pada bidang datar dengan cara di lem (Pamadhi, 2009, h. 56). Melalui kegiatan mozaik anak dapat berkreasi, selain merupakan kegiatan menggambar, melukis, mencetak, dan juga diberikan pengenalan seni aplikasi yaitu kegiatan berolah seni rupa yang dilakukan dengan cara menempel jenis bahan tertentu di atas bidang dasar yang dipadukan dengan teknik melukis.

Dalam penelitian ini peneliti memilih kegiatan mozaik untuk mengembangkan kreativitas anak. Tujuan yang ingin dicapai adalah untuk mengembangkan kemampuan motorik halus anak, serta mampu membuat hasil karya mozaik dengan menyusun potongan-potongan kertas untuk ditempel pada media yang telah disediakan.

Kemampuan motorik halus adalah kemampuan seseorang yang dibawa sejak lahir, dan harus distimulus dengan memberikan pembiasaan pada kegiatan rutin setiap hari agar motorik halus anak berkembang mengikuti rentang usianya dan dapat memberikan bekal bagi kehidupannya dimasa depan kelak dalam menyelesaikan semua tugas yang diberikan. Aktivitas sehari-hari, baik yang sederhana maupun kompleks yang berkaitan dengan gerak. Kegiatan ini 
"Ceria"

\section{Jurnal Program Studi Pendidikan Anak Usia Dini}

sangat membutuhkan koordinasi antara mata dan tangan, karena dalam kegiatan ini memfokuskan pada gerak kecil. Dalam pencapaiannya, kemampuan motorik halus pada usia prasekolah merupakan tujuan dari pengembangan fisik anak. Proses kemampuan motorik sangat erat kaitannya dengan perkembangan pusat motorik di otak sejalan dengan kematangan syaraf dan otot.

Ada beberapa material yang dibutuhkan dalam membuat karya mozaik bahan yang digunakan antara lain adalah kertas, kancing baju, potongan kain, biji-bijian, daun kering, potongan kayu, potongan tripleks yang kecil-kecil, biji korek api, dan lain sebagainya karena seperti dijelaskan di depan bahwa seni mozaik itu sangat banyak bahannya, yang utama adalah kreativitas dalam memilih dan mengajak siswa untuk berekspresi dengan media yang ditentukan (Pamadhi, 2009, h. 5.19)

Langkah-langkah pelaksanaan teknik mozaik yang digunakan oleh peneliti yaitu : a). Guru menyiapkan alat dan bahan kegiatan mozaik, b). Guru mengatur posisi duduk anak dengan kondusif, c). Guru memberikan penjelasan tentang bagaimana anak menempel mozaik dan memberikan arahan, d). Guru dengan anak membuat aturan main, e). Anak mulai melakukan kegiatan, dengan menggunakan alat dan bahan yang telah disediakan, f). Guru mengontrol setiap kegiatan anak, jika ada anak yang tidak bisa/tidak mau mengerjakan guru dapat membantu anak.

Mozaik merupakan sebuah karya yang dihasilkan dari potonganpotongan kertas yang kemudian disusun pada media gambar yang sudah ditentukan. Bagi anak usia dini proses pembelajaran melalui kegiatan mozaik dapat meningkatkan kemampuan motorik halus anak. Melalui kegiatan mozaik anak juga dapat mengembangkan kemampuan social-emosionalnya, anak akan terlatih dan terbiasa bersabar dalam menyelesaikan tugasnnya sampai selesai. Anak lebih mudah mempelajari suatu kegiatan dengan bermain, karena dengan bermain anak dapat menyelesaikan tugasnya dengan hati yang senang tanpa adanya paksaan, sama halnya dengan mozaik. Karena mozaik anak akan lebih 
"Ceria"

Jurnal Program Studi Pendidikan Anak Usia Dini

mudah dalam belajar dan meningkatkan kemampuan motorik halusnya melalui proses pembelajaran yang berlangsung menyenangkan.

Dengan demikian, kegiatan mozaik dapat meningkatkan kemampuan motorik halus anak. Melalui kegiatan mozaik pula dapat mengembangkan kreativitas anak, melatih tingkat kesabaran anak, melatih konsentarsi anak, dan membuat anak menjadi mandiri dan anak dapat berkembang sesuai harapan.

\section{Metode}

Pendekatan penelitian ini dilakukan dengan menggunakan pendekatan Kuantitatif, sedangkan jenis metode penelitian yang digunakan adalah Quasi Eksperiment, dengan subjek penelitian yaitu anak usia (4-6 tahun) di TK AlFalahiyyah Rajeg Kab. Tangerang. Menurut Sugiyono (2011, h, 18), Metode kuantitatif dapat diartikan sebagai metode penelitian yang berlandaskan pada filsafat positive, digunakan untuk meneliti pada populasi atau sampel tertentu, pengumpulan data menggunakan instrumen penelitian, analisis data dan bersifat kuantitatif/statistik, dengan tujuan untuk menguji hipotesis yang telah diucapkan. Menurut Kamus Besar Bahasa Indonesia kuantitatif adalah data berbentuk angka yang diperoleh dari hasil perhitungan data kualitatif.

Metode penelitian yang digunakan adalah metode quasi eksperimen dengan jenis Nonequivalent Control Group Desaign. Peneliti menggunakan dua kelompok yang terdiri atas kelompok eksperimen yang diberi kegiatan mozaik dan kelompok kontrol yang tidak diberi kegiatan melipat. Pada penelitian ini kelompok eksperimen maupun kontrol tidak dipilih secara random. Instrument yang digunakan dalam penelitian ini berupa lembar penilaian berupa daftar checklist, observasi dan tes (Pretes, Treatment, dan Postes). Teknis analisis yang dipakai adalah uji-t. Sebelum menghitung uji-t, terlebih dahulu dilakukan uji prasyarat analisis data yaitu uji normalitas dan uji homogenitas, sedangkan teknik analisis data yang digunakan teknik analisis statistik deskriptif, seperti: a). Tabel distribusi frekuensi, b). Diagram histogram, c). Diagram ogive, d). 
"Ceria"

Jurnal Program Studi Pendidikan Anak Usia Dini

Menentukan mean (rata-rata), e). Menentukan modus, f). Menentukan median, g). Simpangan baku, h). Uji normalitas, i). Uji homogenitas, j). Uji T Separated Varians.

\section{Hasil Dan Pembahasan}

Penelitian ini dilakukan di TK Al Falahiyyah. Pada penelitian ini digunakan dua kelas sampel. Kelas B1 sebagai kelas kontrol yang diajar dengan menggunakan metode pembelajaran konvesional, sedangkan kelas B2 sebagai kelas eksperimen yang diajar dengan menggunakan teknik mozaik. Penelitian dilakukan selama 4 minggu dengan tatap muka sebanyak 6 kali pertemuan. Pokok bahasan yang diajarkan pada penelitian ini adalah perkembangan motorik halus menggunakan teknik mozaik.

Berdasarkan hasil penelitian pretes, treatment dan postes pada kelas eksperimen dan kelas kontrol terjadi peningkatan pada kemampuan motorik halus anak usia 4-6 tahun. Berikut perhitungan data statistik awal (lampiran 10) diperoleh nilai pretes dan postes pada kelompok eksperimen dan kontrol. Berikut ini adalah nilai pretes dan postes kelompok eksperimen dan kontrol yang akan disajikan dalam bentuk tabel distribusi frekuensi, histogram, poligon dan diagram ogive. 
"Ceria"

Jurnal Program Studi Pendidikan Anak Usia Dini

Tabel 4.9

Rangkuman Pretes Kelas Eksperimen dan Kelas Kontrol

\begin{tabular}{lcc}
\hline \multicolumn{1}{c}{ Statistik } & \multicolumn{2}{c}{ Kelas } \\
\cline { 2 - 3 } & Eksperimen & Kontrol \\
\hline Nilai terendah & 14 & 13 \\
Nilai tertinggi & 23 & 23 \\
Mean/rata-rata hitung & 20.76 & 19.04 \\
Modus & 21 & 16.7 \\
Median & 20.5 & 17.41 \\
Varians (S2) & 8.19 & 8.79 \\
Simpangan baku (Sd) & 2.86 & 2.96 \\
\hline
\end{tabular}

Berdasarkan hasil analisis data pretes nilai terendah pada kelas eksperimen adalah 14 dan nilai tertinggi adalah 23, sedangkan pada kelas kontrol nilai terendah adalah 13 dan nilai tertinggi adalah 23. Selanjutnya rata-rata kelas eksperimen adalah 20.76 dan rata-rata pada kelas kontrol 19.04, data tersebut menggambarkan kondisi awal kelas sebelum diberikan treatment. 
"Ceria"

Jurnal Program Studi Pendidikan Anak Usia Dini

Tabel 4.18

Rangkuman Postes Kelas Eksperimen dan Kelas Kontrol

\begin{tabular}{lcc}
\hline \multicolumn{1}{c}{ Statistik } & \multicolumn{2}{c}{ Kelas } \\
\cline { 2 - 3 } & Eksperimen & Kontrol \\
\hline Nilai terendah & 20 & 18 \\
Nilai tertinggi & 24 & 24 \\
Mean/rata-rata hitung & 22.34 & 18.50 \\
Modus & 21.97 & 22.02 \\
Median & 21.95 & 22 \\
Varians (S') & 0.97 & 1.83 \\
Simpangkan baku (Sd) & 0.99 & 1.35 \\
\hline
\end{tabular}

Berdasarkan hasil analisis data postes nilai terendah pada kelas eksperimen adalah 20 dan nilai tertinggi adalah 24, sedangkan pada kelas kontrol nilai terendah adalah 18 dan nilai tertinggi adalah 24 . Selanjutnya rata-rata pada kelas eksperimen adalah 22.34 dan rata-rata pada Jurnal Program kelas kontrol adalah 18.50, data tersebut menggambarkan kondisi kelas setelah diberikan treatment.

Untuk menguji apakah sampel yang diambil berdistribusi normal atau tidak maka digunakan uji Liliefors.

Tabel 4.19

Uji Normalitas Pretes Kelas Eksperimen

\begin{tabular}{|c|c|c|c|c|c|c|c|c|c|c|c|c|}
\hline No & Interval & $\mathrm{fi}$ & fk & $x i$ & fi.xi & $(x i-\dot{x})^{2}$ & $f i(x i-\dot{x})^{2}$ & zi & ztabel & $F(z i)$ & $S(z i)$ & $|F(z i)-S(z i)|$ \\
\hline 1 & $14-16$ & 2 & 2 & 13.5 & 27 & 33.18 & 66.36 & -2.01271 & 0.4778 & 0.0222 & 0.08 & -0.0578 \\
\hline 2 & $17-19$ & 6 & 8 & 16.5 & 99 & 7.62 & 45.71 & -0.96442 & 0.3315 & 0.1685 & 0.32 & -0.1515 \\
\hline 3 & $20-22$ & 9 & 17 & 19.5 & 175.5 & 0.06 & 0.52 & 0.083863 & 0.0319 & 0.5319 & 0.68 & -0.1481 \\
\hline 4 & $23-25$ & 8 & 25 & 22.5 & 180 & 10.50 & 83.98 & 1.132148 & 0.3708 & 0.8708 & 1.00 & -0.1292 \\
\hline 5 & $26-28$ & 0 & & 25.5 & 0 & 38.94 & 0 & 2.180432 & 0.4854 & 0.9854 & 0 & 0 \\
\hline$\Sigma$ & & 25 & & & 481.5 & & 196.56 & & & & & \\
\hline
\end{tabular}


"Ceria"

Jurnal Program Studi Pendidikan Anak Usia Dini

Karena nilai L hitung $=-0.1515<\mathrm{L}$ tabel 0.173 , maka dapat disimpulkan bahwa data berdistribusi normal .

Berdasarkan tabel diatas terlihat bahwa liliefors hitung kelas eksperimen lebih kecil (Lo) dari liliefors tabel (LK) maka sampel berdistribusi normal. Demikian juga pretes kelas kontrol, nilai liliefors hitung lebih kecil (Lo) dari liliefors tabel maka sampel berdistribusi normal.

Tabel 4.20

Uji Normalitas Postes Kelas Eksperimen

\begin{tabular}{|c|c|c|c|c|c|c|c|c|c|c|c|c|}
\hline No & Interval & $\mathbf{F i}$ & fk & $x i$ & fi.xi & $(x i-\dot{x})^{2}$ & $f i(x i-\dot{x})^{2}$ & zi & ztabel & F(zi) & $S(z i)$ & $|F(z i)-S(z i)|$ \\
\hline 1 & $20-21$ & 4 & 4 & 19.5 & 78 & 3.39 & 13.54 & -1.86504 & 0.4686 & 0.0314 & 0.16 & -0.1286 \\
\hline 2 & $22-23$ & 19 & 23 & 21.5 & 408.5 & 0.03 & 0.49 & 0.162177 & 0.0636 & 0.5636 & 0.92 & -0.3564 \\
\hline 3 & $24-25$ & 2 & 25 & 23.5 & 47 & 4.67 & 9.33 & 2.189389 & 0.4854 & 0.9854 & 1.00 & -0.0146 \\
\hline 4 & $26-27$ & 0 & - & 25.5 & 0 & 17.31 & 0.00 & 0 & 0 & 0 & 0 & 0 \\
\hline 5 & $28-29$ & 0 & - & 27.5 & 0 & 37.95 & 0.00 & 0 & 0 & 0 & 0 & 0 \\
\hline$\Sigma$ & & 25 & & & 533.5 & & 23.36 & & & & & \\
\hline
\end{tabular}

Karena nilai Lhitung $=-0.3564<$ Ltabel 0.173 , maka dapat disimpulkan bahwa data berdistribusi normal

Berdasarkan tabel diatas terlihat bahwa liliefors hitung kelas eksperimen lebih kecil (Lo) dari liliefors tabel (LK) maka sampel berdistribusi normal. Demikian juga postes kelas kontrol, nilai liliefors hitung lebih kecil (Lo) dari liliefors tabel maka sampel berdistribusi normal. Perhitungan secara lengkap disajikan pada lampiran 10

Homogenitas dari hasil pengujian data pretes diperoleh hasil sebagai berikut:

Tabel 4.21

Hasil Uji Homogenitas Pretes

\begin{tabular}{cc}
\hline Fhitung & Ftabel \\
\hline $\mathbf{1 . 0 7}$ & 1.98 \\
\hline
\end{tabular}


"Ceria”

\section{Jurnal Program Studi Pendidikan Anak Usia Dini}

Berdasarkan tabel diatas terlihat bahwa F hitung lebih kecil dari F table, menurut kriteria homogenitas jika $\mathrm{F}$ hitung $<\mathrm{F}$ tabel Ho diterima, maka varian kedua sampel homogen, dapat disimpulkan bahwa kedua varian berasal dari populasi yang homogen.

Tabel 4.22

Hasil Uji Homogenitas Postes

\begin{tabular}{cc}
\hline Fhitung & Ftabel \\
\hline 1.88 & 1.98 \\
\hline
\end{tabular}

Berdasarkan tabel diatas terlihat bahwa F hitung lebih kecil dari F tabel, menurut kriteria homogenitas jika $\mathrm{F}$ hitung $<\mathrm{F}$ tabel Ho diterima, maka varian kedua sampel homogen, dapat disimpulkan bahwa kedua varian berasal dari populasi yang homogen.

Tabel 4.23

Uji rata-rata dua pihak pretes

\begin{tabular}{|c|c|c|c|c|c|c|c|}
\hline \multicolumn{3}{|c|}{ Kelas Eksperimen } & \multicolumn{3}{|c|}{ Kelas Kontrol } & thitung & \multirow{2}{*}{ Ttabel } \\
\hline$\dot{\mathbf{x}}$ & $\mathrm{Sd}$ & $\mathrm{S}^{2}$ & $\dot{\mathrm{x}}$ & $\mathrm{Sd}$ & $S^{2}$ & & \\
\hline 20.76 & 2.86 & 8.19 & 19.04 & 2.9 .6 & 8.79 & 2.120 & $2.0<1$ \\
\hline
\end{tabular}

Berdasarkan tabel diatas terlihat bahwa nilai t hitung lebih besar dari nilai t tabel maka Ho ditolak, sehingga berdasarkan kriteria pengujian maka terdapat perbedaan rata-rata pretes kemampuan motorik halus dikelas eksperimen dan kelas kontrol. 
Tabel 4.24

Uji rata-rata dua pihak postes

\begin{tabular}{ccccccccc}
\hline Kelas Eksperimen & \multicolumn{4}{c}{ Kelas Kontrol } & thitung & Ttabel \\
\hline$\dot{x}$ & $\mathrm{Sd}$ & $\mathrm{S}^{2}$ & $\dot{\mathrm{x}}$ & $\mathrm{Sd}$ & $\mathrm{S}^{2}$ & \multirow{2}{*}{11.636} & 2.021 \\
\cline { 1 - 5 } 22.34 & 0.97 & 0.99 & 18.50 & 1.35 & 1.83 & & \\
\hline
\end{tabular}

Berdasarkan tabel diatas terlihat bahwa nilai t hitung lebih besar dari nilai $\mathrm{t}$ tabel maka Ho ditolak, sehingga berdasarkan kriteria pengujian maka terdapat perbedaan rata-rata pretes kemampuan motorik halus dikelas eksperimen dan kelas kontrol.

Berdasarkan hasil penelitian yang dilakukan peneliti dengan menggunakan teknik mozaik, terdapat perbedaan yang terjadi pada kelas eksperimen dan kontrol, yaitu terjadi peningkatan kemampuan motorik halus pada kelas eksperimen dibandingkan dengan kelas kontrol.

\section{Kesimpulan}

Berdasarkan hasil penelitian dan pembahasan dapat disimpulkan bahwa Teknik mozaik dapat meningkatkan motorik halus anak. Hal ini terbukti dengan adanya peningkatan motorik halus dari sebelum diberi tindakan sampai diberi tindakan. Oleh karena itu teknik mozaik merupakan media yang efektif untuk meningkatkan kemampuan motorik pada anak usia dini. Hal ini karena teknik mozaik dapat merangsang jari dan pergelangan tangan anak untuk bergerak, perhatian anak terhadap proses pembelajaran makin panjang, anak mampu mengkoordinasikan mata dan tangan untuk melatih emosional, fokus, dan gerak motorik dalam mencapai aspek perkembangan motorik.

Metode pendukung mempunyai peranan sangat penting dalam peningkatan motorik anak melalui media yang diberikan pada anak. Dalam hal ini metode pendukung yakni pemberian waktu untuk mengeksplor kemampuan 
"Ceria"

\section{Jurnal Program Studi Pendidikan Anak Usia Dini}

motorik halus dengan memberikan motivasi kepada anak agar anak menjadi semangat dan dapat membantu meminimalkan permasalahan yang dihadapi pada saat pembelajaran.

Berdasarkan kesimpulan diatas, ada beberapa hal penting yang dapat ditindak lanjuti yaitu untuk kepada Kepala Sekolah dimana hendaknya dapat menjadi penggerak perbaikan terhadap proses pembelajar dan harus menjaga hubungan baik dengan guru. Karena pihak sekolah harus dapat menciptakan kondisi belajar yang memadai dengan memperhatikan fasilitas dan sarana prasarana sekolah yang menunjang dalam pembelajaran khususnya aspek motorik halus, seperti penyediaan media dan alat-pembelajaran yang lain. Kepala sekolah perlu dan dapat melakukan pemantauan proses pembelajaran dikelas. Untuk guru Kelas dapat mengoptimalkan kegiatan pembelajaran dengan menggunakan media yang dapat merangsang motorik halus dengan alat dan bahan yang aman, menarik minat anak dan antusias terhadap proses pembelajaran; Materi yang diberikan kepada anak hendaklah sesuai dengan konteks kehidupan anak, gambar yang menarik, kata-kata yang sederhana. Penyampaian yang jelas dan menarik sehingga akan merangsang anak untuk menyelesaikan kegiatan samapai selesai. Untuk peneliti berikutnya dapat melakukan penelitian yang serupa dengan penelitian ini, tetapi dalam materi dan pendekatan yang berbeda.

\section{Daftar Acuan}

Departemen Pendidikan Nasional. (2008). Kamus Besar Bahasa Indonesia. Jakarta: PT Gramedia Pustaka Utami

Muharrar, Syakir. ( 2013). Kreasi Kolase, Montase, Mozaik Sederhana. Esensi: Penerbit Erlangga

Mushaf Al-Bantani dan Terjemahnya (2013). Pemprov Banten

Mustofa, Yasin. (2007). EQ untuk Anak Usia Dini dalam Pendidikan Islam. Sketsa 
"Ceria"

Jurnal Program Studi Pendidikan Anak Usia Dini

Pamadhi, Hajar. (2009). Seni Keterampilan Anak. Jakarta: Universitas Terbuka

Peraturan Mentri Pendidikan Nasional Replublik. (2009). Standar Pendidikan Anak Usia Dini: Depdiknas

Sugiyono. (2011). Metode Penelitian Kuantitatif, Kualitatif, dan R \& D. Bandung: Alfabeta

Suyadi. (2010). Psikologi Belajar Paud. Yogyakarta: PT Pustaka Insan Madani 